\title{
Insurgency and Counterinsurgency: Case Study of Manipur
}

\section{Abstract}

The Indian army, from the colonial era has been trained for conventional warfare. They have been used to curb the internal disturbances caused by non-state actors especially against insurgencies in Kashmir and the Northeast. Currently in northern part of India insurgency is the main problem and creates the war like situations like curfew and strike, sometimes which clearly challenges the model of democracy. Insurgency is an organized movement aimed to overthrow or destruct the constitutional government by the use of subversion, terrorism as well as armed conflict. And similar attempts by the state to crush them is known as counterinsurgency. This counterinsurgency often changes its nature to repression and human right violations. The northeast region of India comprised of eight states: Assam, Nagaland, Arunachal Pradesh, Mizoram, Tripura and Sikkim and all eight states have been poorly connected to the mainland India. but all of them has been surrounded by major countries like China, Myanmar, Bangladesh and Bhutan. it is very unfortunate to see that the numbers and information of the entire region is not sufficiently analyzed and communicated to the center, which creates the further misinformation, mismanagement and alienation. At another level, these all conflicts contribute to the violent forms, it has not only affects the Indian sovereignty but also affects the life of various people living in the entire region. As of now, among all of the eight states Manipur remains the most violent states in the north-east India. Manipur comes under the armed forces special power act, 1958. which had made the situation of Manipur from bad to worst. In this paper, I will critically analyze the history of Manipur with respect of AFSPA, 1958 violations of human rights, role of Irom Chanu Sharmila also known as the "Iron Lady" or "Mengoubi" who has been on hunger strike for the 16 years to safe guard the rights of people of Manipur from the draconian law of AFSPA and the actions of Indian government.

Keywords: Insurgency, counterinsurgency, Armed forces special powers act 1958.

\section{Introduction:}

India was declared independent in 1947 and in one night it got the status of largest democracy of the world from a British colony. It has faced a vast array of insurgencies in the major parts like northeast states Manipur, Assam, Tripura, Nagaland ,Mizoram as well in northern part of the India like Kashmir and in Punjab. There is one different type of insurgency is there called naxalist-maoist insurgency in the red corridor of India like Bihar, Jharkhand and Andhra Pradesh. For over last six decades , India as a country is facing great trouble with insurgents and counterinsurgents

Before moving further one need to understands the meaning of insurgency. Insurgency comes under the category of irregular warfare however it has some aims. We can say that although insurgency arise in remote areas of the world ,there they find the support of the common people of the villages . the reason of insurgency broadly falls under the category of ethnicity , religious identity , economic or it may be political as well. In short insurgency is a organized movement aimed to overthrow or destruct the constitutional government by the use of supervision, terrorism as well as armed conflict and similarly attempts by the polity to crush them is known as counterinsurgency (COIN).COIN in post 1945 era became most successful due to trained Indian army and comprehensive network of military academics Well known scholars such as Sinha(2007),Banerjee(2009),Rajagopalan(2007) and Kalayananarman(2003) has contributed widely on the debate of COIN.

\section{Manipur's History}

Manipur ( Kangleipak in ancient times) is one of the eight north eastern state of India. It is surrounded by Nagaland to the north, Assam to the west and Mizoram to the south. Myanmar lies to its east. It has a population of over 2.5 million residing in $22.37 \mathrm{sq} \mathrm{Km}$ of land. Over 90 percent of land is designated as hilly terrain . Imphal is the capital and a major trading 
centre. Manipur is a poor state and it ranked at 30th place (out of total 36 state in India) by GDP contribution. The population in the valley is compromised of Musilms,Nagas,Methis, Kuki and many ethnic tribal communities such as Tangkhul, Thadou, Zeliangrong , Mao, Maram, Poumai, Paite,. These ethnic community are governed by customary law that influence cultural practices ,land ownership and its utilization .

On 15 August 1947, with the lapse of the British India, Manipur became briefly independent, but later Manipur was annexed to India in 1949 and it has left a bad taste which many Manipuri's have never forgotten.

On July 19, 1947 a delegation of Nagas met the Indian nationalist leader Mohandas Karamchand Gandhi at Delhi to discuss the issue of Naga autonomy. Gandhi assured them that they have all the right to become independent and Government or Congress won't oppose it .Nagas expressed concern that Indian government might use military force to absorb the Naga territory by force. Gandhi assured the Naga delegation that he would visit Kohima but post Gandhi assassination , later Government of India brutally crushed the movement . Post 1947, The last ruler of Manipur, Maharaja Bodhchandra Singh , established Manipur State Constitution Act,1947' . It was an attempt to establish democracy in Manipur .

The state assembly of Manipur was inaugurated by the maharaja itself in the month of October 18,1948 but Governor of Assam was very much in favor of merger with India he invites the Maharaja to Shillong for talks and presented a merger agreement with India. However Maharaja clearly refused the agreement and he returned to his beautiful valley but he found that his premises was surrounded by the Indian army personal and he was house arrest and on these circumstances he agreed to sign the merger agreement on September 21,1949. By this, Manipur came under the territory of India. On October 15,1949 both Manipur state assembly and elected council of ministers were dissolved. Puppet elections happened in the valley during November and December ,1951. 30 people were elected but the main architect of democracy had betrayed beautiful valley of Manipur and pushed the Manipur into the half -a- century of bloodshed.

Finally on 1972 Manipur got the statehood and BK Nehru took sworn as a Governor of the state. People in Manipur were fully unsatisfied with the Indian government and this lead to birth of the revolutionary group of Manipur called as people's liberation army (PLA). which has the ideology of underground communist leader Hijam Irabot singh and the main leader of PLA was Bisheshwar Singh.

In response of this Indian government imposed the armed forces special powers act, 1958 in Manipur, which stated Manipur as an disturbed area as well as they have declared the all revolutionary organizations completely unlawful. and the capital of Manipur -Imphal covers with the green covering of paramilitary forces leads to era of little war and insurrection.

The story of Manipur's obliteration starts in the 1950 and currently there are almost 72 armed groups are presented in the valley of Manipur fighting for the rights of the people. Every ethnic groups seems to be arming itself. although their demands are very fragmented. some groups demanding the autonomy from the states, some demands has the political objectives and some has the ethical issues as well.

To sum it up the reasons of insurgency are

Geographic Location

Ethenic differences

No proper political representation

Lack of development

Border issues with neighboring countries

Insurgency from border countries

All of these reasons have formulate insurgency nuisance at Manipur, Central Government's has misused its law AFSAFA to cover up the undemocratic military operation strategy of search and destroy.

\section{Armed Forces ( Special Powers) Act, 1958}


An Act to enable certain special powers to be conferred upon members of the armed forces in disturbed areas in the State of1 [Arunachal Pradesh, Assam, Manipur, Meghalaya, Mizoram, Nagaland and Tripura]

Be it enacted by Parliament in Ninth Year of the republic of India as follows:-

Short title and extent - (1) This act may be called ${ }^{2}$ [The armed Forces (Special Powers) Act, 1958]. 3It extends to the whole of the State of ${ }^{4}$ [Arunachal Pradesh, Assam, Manipur, Meghalaya, Mizoram, Nagaland and Tripura].

Definitions: In this Act, unless the context otherwise requires-

"armed forces' means the military forces and the air forces operating as land forces, and includes other armed forces of the Union so operating;

'disturbed area' means an area which is for the time being declared by notification under section 3 to be a disturbed area';

all other words and expressions used herein, but not defined and defined in the Air Force Act, 1950 (45 of 1950), or the army Act, 1950 (46 of 1950) shall have the meanings respectively to them in those Acts.

Powers to declare areas to be disturbed areas - If, in relation to any state or Union Territory to which this act extends, the Governor of that State or the administrator of that Union Territory or the Central Government, in either case, if of the opinion that the whole or any part of such State of Union territory, as the case may be, is in such a disturbed or dangerous condition that the use of armed forces in aid of the civil power is necessary, the Governor of that State or the Administrator of that Union Territory or the Central Government, as the case may be , may by notification in the Official Gazette, declare the whole or such part of such State or Union territory to be a disturbed area].

The Governor is empowered to declare any area of the State as "disturbed area'. It could not be arbitrary on ground of absence of legislative guidelines; Inderjit Barua v.State of Assam 5 .

Section 3 cannot be construed as conferring a power to issue a declaration without any time limit. There should be periodic review of the declaration before the expiry of six months; Naga People's Movement of Human Rights v. Union of India ${ }^{6}$.

Special Powers of the armed forces - Any commissioned officer, warrant officer, non-commissioned officer or any other person of equivalent rank in the armed forces may, in a disturbed area,-

if he is of opinion that it is necessary so to do for the maintenance of public order, after giving such due warning as he may consider necessary, fire upon or otherwise use force, even to the causing of death, against any person who is acting in contravention of any law or order for the time being in force in the disturbed area prohibiting the assembly of five or move persons or the carrying of weapons or of things capable of being used as weapons or of fire-arms, ammunition or explosive substances;

if he is of opinion that it is necessary so to do, destroy any arms dump, prepared or fortified position or shelter from which armed attacks are made or are likely to be made or are attempted to be made, or any structure used as a training camp for armed volunteers or utilized as a hide-out by armed gangs or absconders wanted for any offence; arrest, without warrant, any person who has committed a cognizable offence or against whom a reasonable suspicion exists that he has committed or is about to commit a cognizable offence and may use such force as may be necessary to effect the arrest; Enter and search without warrant any premises to make any such arrest as aforesaid or to recover any person believed to be wrongfully restrained or confined or any property reasonably suspected to be stolen property

\footnotetext{
1 Subs. By Act 69 of 1986, sec.43 for "Assam, Manipur, Megahalya, Mizoram, Nagaland and Tripura and the Union territory of Arunachal Pradesh" (w.e.f. 20.2.1987.)

2 Subs by Act 7 of 1973, sec. 3 for 'the armed forces (Assam and Manipur) special Powers Act, 1958" (w.e.f 5.4.1972).

${ }^{3}$ Subs by Act 7 of 1972, sec. 4 (w.e.f 5.4.1972).

4 Subs by Act.69 of 1986, sec. 43 for 'Assam, Manipur, Meghalaya, Mizoram, Nagaland and Tripura and the Union Territory of Arunachal Pradesh'(w.e.f 20.2.1987).

5 AIR 1983 Del. 514

${ }^{6}$ AIR 1998 SC 431
} 
Conferment of power on non-commissioned officers like a Havaldar cannot be said to be bad and unjustified: Inderjit Barua v. State of Assam¹.

The armed forces must act in cooperation with the district administration and not as an Independent body. Armed Forces could work in harmony when they deployed in disturbed area: Luithukia v.Rishang Keishing².

Arrested persons to be made over to the police -Any person arrested and taken into custody under this Act shall be made over to the officer in charge of the nearest police station with the least possible delay, together with a report of the circumstances occasioning the arrest. In case of arrest of any person, army authority is duty bound to handover to the officer-in-charge of the nearest police station with least possible delay: Horendi Gogoi v. Union of India ${ }^{3}$.

Protection to persons acting under Act - No prosecution, suit or other legal proceeding shall be instituted, except with the previous sanction of the Central Government, against any person in respect of anything done or purported to be done in exercise of the powers conferred by this Act.

Repeal and Saving - [Repealed by Amending and Repealing Act, 1960 (58 of 1960), First Schedule, sec.2 (26.12.1960]

\section{Human rights violations in Manipur}

"It takes us a long time to raise our childern. then, when they grow up, they are shot. This cannot go on. we no longer want to look for our children in the morgue"

\section{yumlembam Mema, women's right Activist in Manipur.}

We take pride in being the enlightened species on planet earth and yet in our efforts to secure national boundaries or assert the uniqueness or superiority of our ethnicity we would transgress any ethical boundary to have the winning edge. That is a feeling that has gained strength during my recent visit to Manipur and hence this note. When security measures focus primarily on violence; its means, methods, and analysis or countermeasures it ignores - silent spectators in the conflict zone, active impressionable minds that are being molded for life.

\section{I "ll give you one example}

-A women whose name was Thangjam Manorama Devi .32 was arrested at night from her home and on the basis of acknowlegment assam rifels taken her out. in the morning, villagers found her bullet ridden corpse. She has been shot through the lower half of her body ,raising suspicion that bullets had been used to hide evidence of rape. wide protest happens but nothing more than that . The paramilitary forces have claimed that she was shot dead while trying to escape. its very unfortunate and mysterious to look after that a women handcuffed managed to escape the custody of army and if we believe that she can do that then why did the army unable to catch her instead to kill her and how could they arrest a lady in night because soldiers have been empowered through the dacorian law of AFSPA ,1958. emergency law under which they can search , arrest ,short to kill.After Manorama's killing around 32 organization of Apunba Lup started a campaign to repeal the AFSPA and it was very shocking to see the members of this group, Manipuri women on july 15,2004 stripped naked in front of Assam of Assam riffles camp in Imphal, Manipur . they had wrapped a banner around them written "Indian Army Rape Us".

In whole Manipur, people campaigned long for the repealment of the law. Irom chan sharmila had been on hunger strike for 16 long years. she also called Iron lady of the Manipur. she has started her protest after assam riffels gunned down ten civilianson november 2,2000. she was also in judicial ordered custody in which she has been force fed through the nasal tube.but no outcomes come out of her sataygrah.

In the Manorama case a internal inquiry has been set up but nothing comes out. In a interview with human rights watch ,Assam riffles spokesperson said, he could not say what action was taken by the court of inquiry "because the records of

\footnotetext{
${ }^{1}$ AIR, 1983 Del 514

2 (1988) 2 Gau LR 159
} 
concerned officials are not available. Manorama family and people of Manipur are still in the wait of justice. but its a just one example according to human right alert in 2006 there was 17 cases in which security forces allegedly extra judicially executed civilians ,in 200712 cases were documented by the group ; and on 2008 atleast 23 cases.

One more case I will discuss here , Abujam Shidam who was member of opposition Manipur people's party was arrested and tourtered during the custody . he said that he was blindfolded and they have started kicking and beating ,they have poured buckets of water on his face saying that he must admit that he was a member of the PLA( amillitant group in Manipur).

Nothing can explain bullet ridden bodies fired upon from all sides, at times in close quarters. If, elimination is the only solution, then all that a nation would need is trained snipers for cost effective security management, eliminating the need for surplus ammunition, personnel and infrastructure.

Operation Bluebird (1987) is a remarkable example of the approach adopted in the region. The Central Paramilitary forces held a concerned village in terror for months in retaliation for being attacked and losing a large quantity of arms and ammunition. That surely cannot be the way to set up secure boundaries and build bridges of democracy. The state machinery remained helpless and intervention had to come by way of securing the legal rights of citizens, through a public litigation filed in the Guwahati High Court. The hearing was completed after five years but the judgment was kept reserved1. The use of excessive force is not a rare occurrence, in 2009 the indiscriminate use of gun power in broad daylight led to public protests and a subsequent decline of such instances. Excessive force can instill, fear, anger and revenge - Not Peace.

Unlike as in a war against another state, both paramilitary forces and the local population have to survive here, side by side. This complicates the situation, for as indicated by Webel David, there is a possibility of the vicious circle of violence getting strengthened, when violence perpetrators are rewarded for acts of violence this instills feelings of revenge among victims and those sympathetic to them.

It is the skill of the personnel at the ground and their sense to take the right call in a short span of time on a sudden outburst of violence that can restrict excessive damage.

India's obligations under the ICCPR, other human rights treaties and customary international law

India has a series of obligations under international law, both under international human rights treaties and customary international law.

The ICCPR, to which India has been a party since 1979, outlines a series of rights and corresponding obligations that are relevant when interpreting the Act and its application. These include the right to life (article 6), the prohibition of torture, cruel, inhuman and degrading treatment (article 7), the right to liberty and security of the person (article 9), the right not to be subjected to arbitrary or unlawful interference with one's privacy, family, home or correspondence (article 17), the right to freedom of assembly (article 21), as well as article 2(3), which provides for the right to an effective remedy to anyone whose rights protected by the Covenant have been violated.

Since 1968 India has also been a state party to the International Convention on the Elimination of All Forms of Racial Discrimination ("ICERD"). Article 1 (1) of the ICERD defines "racial discrimination" widely as including "any distinction, exclusion, restriction or preference based on race, colour, descent, or national or ethnic origin which has the purpose or effect of nullifying or impairing the recognition, enjoyment or exercise, on an equal footing, of human rights and fundamental freedoms". The ICERD further mandates in article 2(1)(c) states parties "to amend, rescind or nullify all laws and regulations which have the effect of creating or perpetuating racial discrimination".

India signed the Convention against Torture and Other Cruel, Inhuman or Degrading Treatment or Punishment in 1997. Although it has not yet ratified it, under article 18(a) of the Vienna Convention on the Law of Treaties, the very act of signing entails an international obligation not to defeat the treaty's object and purpose. This includes, pursuant to the Convention's 
preamble, the effective struggle against torture and other cruel, inhuman or degrading treatment or punishment throughout the world.

The prohibition of torture and other cruel, inhuman or degrading treatment or punishment, the prohibition of racial discrimination, the right to life, the right to liberty and security and the right to an effective remedy have also been recognised as customary international law. These are rules binding on states as a matter of state practice and opinio juris irrespective of whether or not a state is a party to a particular treaty. 1 Unlike for states parties to a treaty, adherence to customary international law is not monitored by a treaty body but subject to monitoring by UN charter bodies, such as the UN Human Rights Council and its special procedures.2

\section{Supreme Court}

On 27 November 1997 the Supreme Court of India rendered its judgment in Naga People's Movement for Human Rights v. Union of India. 3 In this case the validity of the Act was challenged by means of a writ petition before the Supreme Court of India. The petitioner alleged that the Act had violated constitutional provisions that govern the procedure for issuing proclamations of emergency, and upset the balance between the military and civilian and the union and state authorities. The court rejected those contentions. It found that the parliament had been competent to enact the Act and ruled that its various sections were compatible with the pertinent provisions of the Indian constitution. In particular, the court held that the application of the Act should not be equated with the proclamation of a state of emergency, which led to it finding that the constitutional provisions governing such proclamations had not been breached. The court further emphasised that the military forces had been deployed in the disturbed areas to assist the civilian authorities. As these authorities continued to function even after the military's deployment, the court held that the constitutional balance between the competencies of the military and the civilian authorities had not been upset. Equally, the court found no violation of the constitutional balance of competencies of the union and state authorities. What the court did not address was the compatibility of the Act with India's obligations under the ICCPR or other international obligations. This is notwithstanding the general rule of Indian constitutional law, confirmed by the Supreme Court in another case decided in 1997, that the courts must have regard to international conventions and norms when interpreting domestic statutes. 4

The position of the Supreme Court of India carries immense persuasive weight when interpreting the constitutional vires of the Act. One could argue that the main points of discussion concerning the constitutionality of the Act in Naga People's Movement for Human Rights revolved around the procedures followed during the enactment and the implication of the Act in the centre-state relations. However, the Supreme Court of India has been liberal in reading in international human rights jurisprudence to be applied at the domestic level. For instance, in 1996 the Supreme Court extensively drew inspiration from the General Comment adopted by the Human Rights Committee to decide upon the question of reservations.5 The Court has held on various occasions that although ratified international treaties do not automatically become part of domestic law they are nevertheless relevant to constitutional interpretation, with reference to article 51(c) of the Constitution which directs the state "to endeavour to foster respect for international law and treaty obligations in the dealings of organized peoples with one another". This provision does not confer a justiciable right. It, however, encourages the government to strive to achieve in good faith the objectives of the ratified international treaty through executive or legislative actions. It is this provision that the Indian courts have liberally interpreted to read in within the domestic framework the country's obligation under international human rights law. A fitting case to the point would be the Kesavananda Bharati case.6 The then Chief Justice of India, Justice Sikri, while deciding the case said: "... [i]t seems to me that, in view of Article 51 of the directive principles, this Court must interpret language of the Constitution, if not intractable, which is after all a intractable law, in the light of the United Nations Charter and the solemn declaration subscribed to by India".

The principle was developed further and applied without hesitation in the Vishaka case[cited above] where the Court said:

\footnotetext{
1 Opinio juris denotes the sense of a certain practice being followed as a matter of legal obligation. See North Sea Continental Shelf (Federal Republic of Germany v. Denmark and Netherlands), International Court of Justice, Judgment of 20 February 1969, I.C.J. Reports, 1969, at para. 77.

2 UN General Assembly Resolution 60/251 of 3 April 2006, at paras. 2-3.

31998 AIR 431.

4 Vishaka et al. v. State of Rajasthan et al., 1997 AIR 3011.

5 T.M.A. Pai Foundation et al. v. State Of Karnataka et al., 1996 AIR 2652.

${ }^{6}$ Kesavananda Bharathi vs. State of Kerala, (1973) Supp. SCR 1.
} 
[l]n the absence of domestic law occupying the field to formulate effective measures to check the evil of sexual harassment of working women at all work places, the contents of International Conventions and norms are significant for the purpose of interpretation of the guarantee of gender equality, right to work with human dignity in Articles 14, 15, 19(1)(g) and 21 of the Constitution and the safeguards against sexual harassment implicit therein. Any international convention not inconsistent with the fundamental rights and in harmony with its spirit must be read into those provisions to enlarge the meaning and content thereof, to promote the object of the Constitutional guarantee.

It follows that under Indian domestic law, wherever possible, a statutory provision must be interpreted consistently with India's international obligations, whether under customary international law or an international treaty. If the terms of the legislation are not clear and are reasonably capable of more than one meaning, the treaty itself becomes relevant, for there is a prima facie presumption that the parliament does not intend to act in breach of international law, including therein, a specific treaty obligation; and if one of the meanings which can reasonably be ascribed to the legislation is consonant with the treaty obligations and another or others are not, the meaning which is consonant is to be preferred.

Considering the question of domestic applicability of the principles of customary international law the court did not have any hesitation in holding that:

[O]nce these principles are accepted as part of the Customary International Law there would be no difficulty in accepting them as part of the domestic law. It is almost accepted proposition of law that the rules of Customary International Law which are not contrary to the municipal law shall be deemed to have been incorporated in the domestic law and shall be followed by the Courts of Law.1

Despite all these affirmative and progressive steps in its pertinent jurisprudence, when it came to interpreting the Act, the court fell short of its own established practice and failed to interpret the Act in compliance with India's international human rights obligations and the treaty obligation under the ICCPR in particular.

Yet, there is hope, since the court did not merely say that the AFSP Act is constitutional and leave it at that. By way of caution, probably reading in the arbitrary nature of the powers conferred by the Act to the persons working under the Act, the court set out some precautions for the implementation of the Act as follows:

While exercising the powers conferred under clauses (a) to (d) of Section 4 the officers of the armed forces shall strictly follow the instructions contained in the list of Do's and Don'ts issued by the army authorities which are binding and any disregard to the said instructions would entail suitable action under the Army Act, 1950. The instructions contained in the list of Do's and Don'ts shall be suitably amended so as to bring them in conformity with the guidelines contained in the decisions of this Court and to incorporate the safeguards that are contained in clauses (a) to (d) of Section 4 and Section 5 of the Central Act as construed and also the direction contained in the order of this Court dated July 4, 1991 in Civil Appeal No. 2551 of 1991.

There has been no effective review of these directions so far. For instance, the Central Bureau of Investigation of India only lists 118 applications that sought prior sanction for prosecution, of which only five are from Manipur. This is contrary to the statistics available as to the number of civil cases in which Indian courts have awarded monetary compensation to victims. If the number of writ petitions-from Manipur itself there have been more than two dozen cases-is an indicator of the extent of violations of the Supreme Court's directives, it is time for an effective review of the AFSP Act. It is also important to note that a remedy under the writ jurisdiction is not punitive in nature. A prosecution by means of the "procedure established by law" has never happened.2

\section{Committee to review the Act set up by the government}

\footnotetext{
1 Vellore Citizens Welfare Forum v. Union of India et al., 1996 AIR 2715.

${ }^{2}$ A case that could be considered to have come close is Sebastain M. Hongray v. Union of India et al., 1984 AIR 571, where a writ of habeas corpus was filed before the Supreme Court of India concerning the disappearance of two persons, Mr. C. Daniel and C. Paul, since their arrest from Huining village in Manipur on 10 March 1982. The court by its order dated 24 November 1983 allowed the writ petition, thereby directing the respondents 1,2 and 4 in the case to produce the corpus of the two missing persons on 12 December 1983 before the Court. The outcome of the case since then is not known.
} 
The Union Ministry of Home Affairs set up a committee chaired by a retired justice of the Supreme Court B. P. Jeevan Reddy with the remit to review the provisions of the Act and report to the government on whether amendment or replacement of the Act would be advisable. 1 Having conducted extensive studies and consultations, the committee reported in 2005 that it had formed "the firm view" that the Act should be repealed as "too sketchy, too bald and quite inadequate in several particulars", emphasising that "recommending the continuation of this Act, with or without amendments, [did] not arise".2

The committee felt it necessary to further specify the following: "We must also mention the impression gathered by it during the course of its work that the Act, for whatever reason, has become a symbol of oppression, an object of hate and an instrument of discrimination and high-handedness".3

These recommendations were never carried out and the report itself was not officially made public.

In addition to the Jeevan Reddy Committee, the Second Administrative Reforms Commission in its fifth Report of 2007 also recommended the repeal of the AFSP Act. The Commission stated that "after considering the views of various stakeholders [it] came to the conclusion that AFSP Act should be repealed".4

\section{International review}

\section{Human Rights Committee}

The Act was scrutinized on two occasions by the Human Rights Committee, a body composed of independent experts that is established specifically to monitor the implementation of the ICCPR by its states parties.

The Committee first raised questions about various provisions of the Act, such as the scope of the authorisation to use lethal force, in 1991, during the consideration of India's second state party report on its compliance with the ICCPR. In particular, the Committee

[l]nquired to what extent [the Act was] consistent with provisions of the Covenant relating to the physical integrity of the person and the obligation to bring a person to trial with the least possible delay and, more generally, to provisions relating to preventive detention and article 4 of the Covenant; whether the authorization of the use of force even to the causing of death in accordance with [the Act] was compatible with article 4, paragraph 2, and article 6 of the Covenant.5

In 1997 the Committee, while considering India's third periodic report, emphasised that all measures taken by India in order to protect its population against terrorist activities must be in full conformity with its obligations under the ICCPR. 6 It further expressed its hope, in vain as it turned out, that the Supreme Court would examine the provisions of the AFSP Act for their compatibility with the ICCPR in the context of the then pending proceedings in Naga People's Movement for Human Rights v. Union of India.

The Committee specifically underscored its concern about the fact that the Act had remained in force in certain areas of India - such as Manipur - for decades, thus effectively making emergency powers permanent without formally derogating from the ICCPR. It further stressed that decisions on continued detention must be taken by an independent and impartial tribunal and that a central register of detainees be maintained and shared with the International Committee of the Red Cross.

\footnotetext{
1 The committee had as its members (1) Dr. S. B. Nakade an academic and jurist; (2) Mr. P. Shrivastav (IAS) former Special Secretary, Ministry of Home Affairs; (3) Lt. Gen. V. R. Raghavan; and (4) Mr. Sanjoy Hazarika, journalist.

[

${ }^{2}$ Government of India, Ministry of Home Affairs, Report of the Committee to review the Armed Forces (Special Powers) Act, 1958

(2005), at 74 .

${ }^{3}$ Report of the Committee, at 75.

${ }^{4}$ Second Administrative Reforms Commission Report, Report 5 - Public Order (June 2007), at 239.

${ }^{5}$ Human Rights Committee, Report to the General Assembly, UN Doc. CCPR/46/40 (10 October 1991), at para. 268.

${ }^{6}$ Human Rights Committee, Concluding Observations on the Third Periodic Report of India, UN Doc. CCPR/C/79/Add.81 (4 August 1997), at paras. 4 and 18.
} 
The Committee noted with concern [at paragraph 23] the "allegations that... security forces do not always respect the rule of law and that, in particular, court orders for habeas corpus are not always complied with, in particular, in disturbed areas".

On a more general level, the Committee reminded India that immunity provisions, such as those found in the AFSP Act, are incompatible with the right to an effective remedy under international human rights law and the concomitant duty to investigate and prosecute gross human rights violations, such as torture. It expressed [in paragraph 21], in particular, its concern

That criminal prosecutions or civil proceedings against members of the security and armed forces, acting under special powers, may not be commenced without the sanction of the central Government. This contributes to a climate of impunity and deprives people of remedies to which they may be entitled in accordance with article 2, paragraph 3, of the Covenant.

The fourth periodic report of India to the Committee pursuant to article 40 of the ICCPR was due in 2001. It has not yet been submitted, which means that it is overdue by 10 years at the time of writing. The Government of India should ensure that the report is prepared and submitted to the Committee at the earliest possible date.

It appears that the Committee still hesitates to use this power in the case of India. If the report is not submitted in the nearest future, the Committee should be prepared to re-consider its position and assess India's performance in terms of compliance of its law and practice with the ICCPR in the absence of the state report. 1 The existence and application of the AFSP Act should in this case be among the primary concerns of the Committee, and international and domestic non-governmental actors should take a lead in providing it with examples that illustrate how different provisions of the Act have been applied on the ground.

Human Rights agencies are trying to address concerns of individuals victimized or adversely affected by existing conflict. These agencies have come together under a platform known as Civil Society Coalition of Human Rights in Manipur to assert the human rights perspective at the national and international level. There is need for government to create a sense of accountability through speedy trials and the provision of compensation for deaths or injury to civilians. Isn't standing up for Justice a part of one's sovereign democratic rights within a nation? The nation also owes that to the armed forces for if it is injustice is all what they are capable off, then India would not be a functioning democracy. the indian government claimed to have a firm commitment for the protection of human rights and called these act as "few bad apples". this culture of impunity, grows by the lack of political willand dacorian law AFSPA which has led a atmosphere of unrest and firm believe of army that they can get away with the most serious crime without the threat of punishment.its very unfortunate to see that government and the committies which has been led by the government has ignored all the recommendation made by the United Nation human rights bodies .

In 1977, UN Human Rights committee said that the use of AFSPA was tantamount to using emergency powers and also recommended the application of these powers should be monitored to ensure compliance with the International convent on civil and political rights(ICCPR). Philip Alton, UN special, reporter on extrajudicial summary also reported to the human rights council in 2007 , that despite the government of Manipur ordering "numerous inquiries" into the alleged extrajudicial executions ,none of them ultimately reached any meaningful conclusion. Committee of international conventions also called for repeal of AFSPA. We can see several recommendations of different committees have taken place to repeal the AFSPA but so far not happens.

\section{Critical Issues}

Government schools have systemically turned dysfunctional with many having shut down. At the same time private schools are mushrooming in the valley area as are tuition centers. This limits options for the education of children from poorer families and from rural areas. As primary education is compulsory students are automatically given pass marks and government records naturally show an improvement in education till primary school.

The elite send their children to other states or to private schools in Manipur and for private tuitions. A student ends up spending nine hours on rote learning at school and then tuitions. Tuitions have turned a thriving business with advertisements that try to entice 6 year olds (Std II) to seek their services.

\footnotetext{
${ }_{1}^{1}$ Revised Rules of Procedure of the Committee, UN Doc. CCPR/C/3/Rev.9 (13 January 2011), Rule 70(1).
} 
Government institutes in hill districts face additional problem of absentee teaching staff. Schools are dependent on human resource from the valley, which invariably join the service but report only to collect their monthly remuneration. The teacher contracts her/his job to a local person for a meager amount.

This lack of accountability has led to a situation whereby students are trafficked after being lured with the promise of a better education outside with boarding facility. Newspaper reports indicate such trafficked children as sent by their family for the contact person was usually someone known and working in another state. As the provision of educational services has not changed drastically, the present scenario may indicate an under reporting or difficulties in detection. Government intervention has been largely limited to creating awareness on the situation through wall posters and creating children's homes. The recent instance of a girl child running away from a children's home because of sexual abuse by a person in charge of institution indicates the situation is far from smooth ${ }^{1}$.

While schools are mushrooming, only a select number of schools are allowed to enroll students for the final board exams for classes X to XII. This does create logistical problems and chaos as students have found their enrolment for exams turn invalid. Many of the schools permitted to conduct these exams are in the valley and that restricts girls of the hill districts seeking a higher education. The number of schools catering to girls is far less than those for boys.

There is hardly any focus on career guidance other than educational streams as medicine or engineering for the elite, with huge donations paid to institutes within and outside the state.

Health care service delivery is shaped by the same problems as the educational services of the State. Rural areas are burdened by a dependence on professionals from the valley area and this means erratic delivery or an absence of service. There is an attempt to use technology to facilitate access to health service, but extended hours of power cuts/load shedding raises questions. According to key informants the National Rural Health Mission has been able to bring about some positive change. Besides, each ethnic group turns to traditional systems of care for many common ailments, measures to strengthen those systems of care is limited.

\section{Conclusion}

The tug of war on position based negotiation that leads to an absence of dialogue is not working for the local population, certainly not for future generations who are losing out on the comfort of family, with the rising incidence of broken families. The disparity between classes will only grow if the present form of governance continues; this may even complicate the situation far beyond the expectations of underground groups. A conflict reality is what children have been born into and this frame of reference is continuously imprinted when corruption, money, power and useful links/associations are seen as part of the survival game. The children will learn at a very young age life is a conflict and the 'winner take all'.

Though the Central Government of India is doing their bits to improve the condition in the past two decades the policies like the 'Look East Policy' and other programs reaching the far and wide part of the North Eastern States, the crime on the border still continue to take place. Lives are still lost, youths are still lured into drugs and insurgency and families are still in trauma. Some stringent steps need to be taken up to curb the border menace. Policies must be implemented between the neighboring countries, better relations and co ordinations with the Myanmar regime might put an end to the operation of cross border activities. Myanmar and North Eastern part of India remain largely unexplored in terms of natural gas and rich minerals, to utilize this the cross border crime must be curtailed, which in turn will put an end to the existing insurgency and the drug trafficking. Only then the Look East Policy and other developmental policies will be able to bear fruit. The porous border must be checked thoroughly and effective plans must be chalked out to fill in these borders. The BSF should play an active role in strengthening and securing the border area. If the cross border crime is to be curtailed the North Eastern States should at first be prosper economically, only then the crime rate will come down. The youths are needed to be provided awareness about the situation as they are the most targeted lots in such crime. A prosper economy will lie on good education, employment to the youths. 


\section{Bibliography}

[1] Acharya, S. K. 1990. "Ethnic Processes in North-Eastern India," in D. Pakem (ed). Nationality, Ethnicity and Cultural Identity in North-East India. New Delhi, Omsons Publications: pp. 69-108.

[2] Barbora, Sanjay. 1998. Plantation Systems and Labour Movements in North East India. Delhi: Dept. of Sociology, Delhi School of Economics (Unpublished Mphil. Thesis).

[3] Benjamin Gondaimei. "Movements for Human Rights in Manipur." 2012, Downloaded from http/l www.kanglaonline.net. Accessed 09/02/2013.

[4] Bhaumick, Subir. 2003. "Tripura's Gumti Dam Must Go," The Ecologist Asia 11 (n. 1, Jan.-Mar), pp. 84-89.

[5] Victoria Chioma Nwankwo. The Role of the Media in Promoting Human Rights: An Analysis of the BBC documentary, Chocolate: the bitter truth [M.A Dissertation]. Gothenburg : University of Gothenburg ;2011 